\title{
Linda Hogan
}

\section{Dr. Ahmad Mohammad Abd Al-salam Ahmad}

\author{
Assistant Professor of English Literature \\ Department of English Language and Literature, Faculty of Arts, Fayoum \\ University
}

\begin{abstract}
:
Ecofeminism, otherwise known as "ecological feminism", defines a branch of the feminist theory that explores the interconnectedness of two fundamental considerations- nature and women. The name 'ecofeminism' can best be conceptualized as the authorship of Françoise d'Eaubonne, a French feminist whose work emphasized the connection between social and environmental matters. Unlike the feminist theory whose major concern is addressing the oppressions of women in society, ecofeminism uses the fundamental feminist characteristics of gender equality. It represents a revaluation of the nonlinear or non-patriarchal structure, and shows a great respect for organic processes to foster the value of collaboration, holistic connectedness, and the benefits of intuition. The principle purpose of this paper is to explore the theme of ecofeminism as represented in classical and contemporary poetry, with particular emphasis on the works of two influential poets- Fadwa Tuqan and Linda Hogan. An analysis of Tuqan's and Hogan's poetic works shows strong ideas of ecofeminism, and this justifies the selection of their works in exploring the theory that explains nature in the context of patriarchal dominance. In essence, both Tuqan and Hogan gain their rightful appreciation as ecofeminists who have managed to use their poetic wits to advocate for an ecological philosophy, where the connection between humanity and nature is viewed as one that demands to be fixed through respecting the differences and similarities between the two. The works of the two poets, as described in preliminary facets of the evaluation, show significant similarities between the early Palestinian concept of ecofeminism and that of contemporary American ecofeminist in that both deal with the themes of women and nature versus a male-centred society. Tuqan and Hogan go a long way using their feministic poetry to describe the destruction of nature as consequences of conceptual separation between nature and human beings. Both also believe that the problem could be solved through accepting a new ecological theory that accepts humanity as an integral part of nature, and women as equivalents of men.
\end{abstract}

Key Words: Ecofeminism, Fadwa Tuqan, Linda Hogan, women and nature, interconnectedness 


\section{Introduction}

The contemporary society is gradually abandoning the positivist perspective of visualizing the environment and adopting the argument that reality is too complex to be understood by the aid of the laws of natural science. The same notion pervades Hadeed's work, bearing in mind his subscription to the interpretivism notion that there are innumerable ways of conceptualizing the environment. In essence, the contemporary society has shown the tendency to consider new human interpretations in describing the world around them even as the globe experiences a pandemic loss of biodiversity and as industrial practice cause humanity to skew away from the earth. Considering fresh ways of describing reality gains additional relevance now as the problem of pollution persists and as people suffer the harsh consequences of construction projects, otherwise justified as development (Kronlid 13). Grouping subjugated groups and women with nature paves the way for understanding environmental and social environmental injustices from a peculiar perspective that encourages solace and solidarity (Shiva, Maria, \& Ariel 32). The principle purpose of this paper is to explore the theme of ecofeminism in classical and contemporary poetry, more so by focusing on the works of two influential poets- Fadwa Tuqan and Linda Hogan.

\section{The Theory of Ecofeminism}

Ecofeminism, otherwise known as "ecological feminism" defines a branch of the feminist theory that explores the interconnectedness of two fundamental considerations- nature and women. The name 'ecofeminism' can best be conceptualized as the authorship of Françoise d'Eaubonne, a French feminist whose work emphasized the connection between social and environmental matters (Laroche \& Jennifer 22). She was the first one to refer to the term Ecofeminism. She stresses the connection between Feminism and environmentalism when she "called for a feminist revolution to ensure ecological survival' (Howell 231). Thus, it combines feminists and ecologists in the sense that both are oppressed in patriarchal societies. Since then, a growing number of critics have been concerned with showing this connection between the domination of women and the domination of nature.

Darcy de Oliveira Rosiska also emphasizes this interrelation between women and nature. She admits that women have a special care 


\section{Dr. Ahmad Mohammad Abd Al-salam Ahmad}

for others and that "their identity is formed in their interaction with others. For this reason, women are more intuitive, more sensitive, and more empathetic". (149) Karen Warren contributes to making this interconnection more explicit. She suggests that ecofeminism should be grounded on some claims. Both women and nature are oppressed in a way that makes them interconnected. She proposes that:

(ii) understanding the nature of these connections is necessary to any adequate understanding of the oppression of women and the oppression of nature; (iii) feminist theory and practice must include an ecological perspective; and (iv) solutions to ecological problems must include a feminist perspective. (4-5)

Hence, Ecofeminism has become more than a feminist or ecological perspective. It has become as Sandilands suggests "a theory and movement which bridges the gap between feminism and ecology, but which transforms both to create a unified praxis to end all forms of domination" (3). A basic assumption of ecofeminism holds that the patriarchal domination of women is interconnected with the domination of nature. It becomes evident that Warren tends to describe ecofeminism in terms of oppression. Both women and nature are originally feminine and have their patterns of suffering from injustice and impairment. She proposes a new conception of ecofeminism. It is a multicultural theory that combines all women with disregard to their different attitudes. Moreover, Warren admits the shortcomings of both Feminism and environmentalism when tackled alone. She suggests that they complement each other.

This tendency of a multicultural and transcultural treatment of ecofeminism is emphasized by Rosemary Radford Ruether. She connects ecofeminism and Liberation of women.

Women must see that there can be no liberation for them and no solution to the ecological crisis within a society whose fundamental model of relationships continues to be one of domination. They must unite the demands of the women's movement with those of the ecological 
movement to envision a radical reshaping of the basic socioeconomic relations and the underlying values of this society. (204)

Ruether calls for a revolution by women to have a new vision of saving oppressed women and mistreated nature. No liberation can be attained in "a society whose fundamental model of relationships" is one of domination. The only solution for women and nature crisis is to unite the demands of the women's movement with those of the ecological movement" in order to "envision a radical reshaping of the basic socioeconomic relations and the underlying values of this society" (204).

The interconnectedness between women and nature is emphasized by many critics. In The Death of Nature. Women, Nature, Ecology and the scientific Revolution(1989), Carolyn Merchant refers to the idea of Nature as being female; an idea which is deeply rooted in the Romantic thought. She denotes that nature, especially the earth, is tackled as " $a$ nurturing mother". It is a "kindly beneficial female who provided for the needs of mankind in an ordered planned universe" (2). Likewise, "Mother Nature and Mother Earth "are expressions extensively used in the Romantic poetry. It is a metaphorical link between women and nature since both have the gift of reproduction and donation. They are considered a bountiful resource of goodness that seems never to be exhausted. In "The Immortality Ode", William Wordsworth stresses this idea of "Mother Nature" who cares for all men. She is "The homely Nurse doth all she can" in order to "make her Foster-child, her Inmate Man".

Earth fills her lap with pleasure of her own;

Yearnings she hath in her own natural kind,

And, even with something of a Mother's mind,

And no unworthy aim,

The homely Nurse doth all she can

To make her Foster-child, her Inmate Man,

Forget the glories he hath known,

And that imperial palace whence he came. 
Nature is depicted as a mother who has the supreme power. It is the mother-like-nourishing power for all. Basically, women have a role of serving the needs of men and they are seen to be inferior to men who claim to have the intellectual power to dominate them. Likewise, nature is regarded as a resource for food, shelter and all human wants. Both women and nature are oppressed in a patriarchal society that gives much care for males over females, the human over the non-human nature. So, eco-feminists regard the oppression of women and nature as interconnected. It is the role of eco-feminism to tackle such injustices and attempt to solve the problems of degradation and social injustice. According to Greta Gaard, ecofeminism is "More than a theory about feminism and environmentalism, or women and nature, as the name might imply, eco-feminism approaches the problems of environmental degradation and social injustice from the premise that how we treat nature and how we treat each other are inseparably linked" (Gaard 2001: 157-172).

The theory of ecofeminism, unlike the feminist theory whose major concern is addressing the oppressions of women in the society, uses the fundamental feminist characteristics of gender equality, a revaluation of the nonlinear or non-patriarchal structure, and respect for organic processes to foster the value of collaboration, holistic connectedness, and the benefits of intuition.

Today's theory of ecofeminism is tangential to a series of workshops and conferences held between the 1970's and the 1980's by groups of women and women professionals in the US. These meetings were cantered on discussions of strategies for incorporating environmentalism and feminism to support respect for the natural world and women. The same found justification on the long historical association between nature and women that lead to the repression of both. In the light of findings that showed that women were often described as irrational, chaotic, and in need for directives from men, ecofeminist came together to device hierarchical frameworks that distributed power between men and women, thereby solving the predicament of nature and women. As such, historical ecofeminism majorly consisted of efforts to document the long association between the environment and women and 
the steps to counter those associations. Consequently, early ecofeminists believed that ending the denomination of nature as a major step towards the liberalization of women from systems that supported social, economic, and political disparity. The challenge was endeavoured by subsequent female activists who started critiquing ecological concepts that overlooked the impacts of patriarchal mechanisms and feminist ideas that failed to interrogate the association between nature and women.

Ecofeminism, as a concept, supports commitment to the natural surrounding and awareness of the connection between women and nature by concentrating on the manner in which the patriarchal society treats both women and nature. The theory goes a long way examining the impacts of gender groups as a way of demonstrating how social systems exert unjust dominance over nature and women. The central argument of the philosophy is that the norms of the man-centric society lead to a partial understanding of the world, and its supporters advocate a different view of the world that recognizes how human beings depend on nature. The influential ecofeminists, Laroche and Jennifer, contend that the globe should adopt the theory as one that values the earth as a scarce resource and embraces all forms of life as important (Laroche \& Jennifer 12).

Ecofeminism presents a conceptual framework that could help in reorganizing people's connection with their surroundings. The theory addresses the suppression of marginalized people and women in particular. This manner of thinking and reorganization opens up possibilities for fresh environmental and human connections that have a wider perspective and less explicit social recognition. The subsequent section seeks a deeper comprehension of the concept of ecofeminism is by exploring the evolution of the theory through works of Fadwa Tuqan and Linda Hogan.

\section{Ecofeminism in Fadwa Tuqan's Poetry}

Fadwa Tuqan, a Palestinian poet, was born in a renowned family in the west end of Nablus City, in the era of Balfour Declaration, which foreshadowed the ultimate deposition of Palestinians from their motherland. A close evaluation of Tuqan's work shows a deep reflection of loss, anger, and pain that she and her people experienced in the war that caused them to flee their area of comfort and find solace in a foreign 
land as refugees. It is by this terrible experience that Tuqan finds the courage to use her poetic intelligence in encouraging Palestinians to gather strength and return home. Although the majority of Tuqan's works focus on the aftermath of war because of Israel's unjust doing, she found exceptional success in addressing the struggles of women in a male-focused Arabic environment. Her work advanced from a more structured and formal style that pervaded the poetry of the early parts of the 20th century to verses that were free in both form and presentation. By the time of her death (2003), Tuqan had developed a strong contact with the concept of ecofeminism, which explains why her works, including "the Deluge and the Tree," "Enough for Me," "A Prayer to the New Year," and, most importantly, "Labor Pain" exits at the top of poems that are deeply rooted in ecofeminism.

Tuqan's "Labor Pain" is one example of poetic works that explore the theme of nature and feminism and this is vivid right from the topic of the poem. The poem begins on a light note, taking her audience through the natural process of plant reproduction where the wind blows pollen grains across "...homes" to a place where its biological infusion triggers new life. It takes not more than the first two lines of the first stanza for the poet to highlight the ecofeminist association between the human body and "..ruin of fields," which Tuqan symbolically uses to describe the natural state of the earth versus "...homes." This association enables Tuqan to bring to context the connection between humanity and nature, acknowledging the influence of human development and settlement on nature. Tuqan describes the act of lovemaking as one characterized by the "Earth shivering with love," which stands for the sensitive woman's body that experiences what could be described as a range of overwhelming pleasure to excruciating pain to enable the continuity of the cycle of life. The persona, a woman, is visualized as the core of life, bearing in mind her sacrificial roles at the end of what begins and ends as a pleasuring experience to the "he" in the poem. The poem strikes a feminist notch when the persona describes the "he" as a "conqueror" who, above all, proliferates the gospel of female submission-though not explicitly stated in the poem, which could show Tuqan's disapproval of the male-cantered Arab society. She goes ahead advise "Arab Aurora," a female character in the poem, to claim her position in the society by 
reminding her that she, like "the sacred land" that receives and supports the seeds of the thorny rose plant, gives life through pain and blood (Hadeed 41).

It is true that Tuqan's work shows an outstanding peculiarity, one that would rightly associate her with Middle-Eastern ecofeminist who tie the fate of women with that of nature. The argument comes out clearly in the presentation of her autobiography in "A Mountainous Journey" where Tuqan describes how her mother, burdened by parenthood, sorted to abort her as the seventh child. She uses the poem to expose her suffering experiences as an unwanted and neglected child and uses this experience to draw a connection between her own experience with Palestine's surfacing into a time of hostility. Although the poem seems to have roots in the time when the British colonial power had established full occupation of the Palestinian land, Tuqan goes further showing the colonial presence had a comparatively lesser negating impact on the life of women than that of the forces acting within families and homes. The two poems- "Labour Pain" and "A Mountainous Journey"- provide an evidence to the notion that Tuqan, being a woman from an environment that is engulfed in suffering, finds the maltreatment of the members of the female gender to be an outcome of both male dominance and oppression by external forces.

Actually, Fadwa Tuqan appears as a participating force and a female voice offering visions peculiar to her about women, love and homeland during the second half of the twentieth century. She manages to have love and nationalism mingled with the image of homeland rooted in the heart. She manipulates ecofeminist metaphorical devices to serve twofold purposes: the elevation of a homeland and the identity of women in a patriarchal society. She admits:

In my homeland, $\mathrm{O}$ poet,

In my precious homeland,

There waits a lover,

A fellow countryman;

I shall not waste his heart ...

I am a female, so, whenever you whisper

Stroke, my heart, please

Forgive its vanity. (Tuqan) 


\section{Dr. Ahmad Mohammad Abd Al-salam Ahmad}

Fadwa Tuqan is the poet of love and pain as well as nationalism within the two emotions. Her poetry deals with an ecofeminist depiction of personal and national love showing the role of women in the resistance. It is not only the resistance of the colonizer but of the oppression of women in such a patriarchal society.

In "The Deluge and the Tree", Tuqan utilizes nature in an ecofeminist manipulation of imagery to set the scene for a kind of resistance peculiar to her. She combines all elements in one image to depict those who are forced to leave their homeland. However, one day they will come back to the land. They are like the bird that leaves its nest for some time but comes back at last. The image is tackled in an ecofeminist treatment.

\section{The Deluge and the Tree}

When the hurricane swirled and spread its deluge

of dark evil

onto the good green land

'they' gloated. The western skies

reverberated with joyous accounts:

"The Tree has fallen!

The great trunk is smashed! The hurricane leaves no life in the Tree!"

Had the Tree really fallen?

Never! Not with our red streams flowing forever,

not while the wine of our thorn limbs

fed the thirsty roots,

Arab roots alive

tunneling deep, deep, into the land!

When the Tree rises up, the branches

shall flourish green and fresh in the sun,

the laughter of the Tree shall leaf

beneath the sun

and birds shall return.

Undoubtedly, the birds shall return.

The birds shall return. 
Metaphors are used to affirm the Palestinian Identity and the dream of return. The images do appeal to nature to use natural objects as central vehicles reflecting the poet's resistance and attitude towards the colonizer. The "hurricane swirled and spread its deluge" with its "dark evils" to represent the colonizer with its vicious and destructive authority. It "leaves no life in the tree". However, the tree with its huge trunk symbolizes Palestine to signify a powerful nation with a powerful resistance. It never falls with the "red streams flowing" and the "wine of thorn limbs" feeds "the thirsty roots". They have their "roots alive" and deep into the land.

Tuqan successfully interconnects three forces of resistance, human and natural combined with the feminine vision at the centre of the images. The tree image is used with Palestine in order to refer to the power of the nation which stems from the enthusiasm and patriotism of its resisters. It is used to symbolize the strength of the Palestinians in the face of the colonizer who is symbolized as a hurricane that cannot affect the strong tree deeply rooted in the land. Blood to the body is like resistance to Palestine. It is the core of resistance. So, the branches will "flourish green and fresh in the sun," and the "birds" will eventually "return".

Birds leave their homes temporarily to come back later on. This image symbolizes the exiled Palestinians who are forced to leave their homeland under the oppression of the colonizer but they, like birds, will come back:

and birds shall return.

Undoubtedly, the birds shall return.

The birds shall return (Tuqan)

Images of return to the homeland are manipulated in an ecofeminist way that is peculiar to Tuqan. This return might be in death and not in life.

Shall I live here and die in a foreign land?

No! I will return to my beloved land,

I will return, and there will I close the book of my life,

Let the noble soil tenderly cover my remains; (Tuqan) 
It depicts the overwhelming experience of the Palestinian women in exile. They yearn for the return to homeland as birds do at last. It is enough for them to die and to be buried in the soil of the homeland. Once buried, the body would be united with earth and becomes a part of the land.

Enough for me to die on her earth

Be burried in her

To melt and vanish into her soil

Then sprout forth as a flower

Played with a child from my country.

Enough for me to remain

In my country's embrace

To be in her close as a handful of dust

A sprig of grass a flower. (Tuqan)

Although the language is simple, the poem has layers of meanings. Given such simplicity of language, one is directed to the role assigned for the poet before and even after death. The poem is the burning spark that kindles the fire of resistance and nourishes the perseverance of its existence with the body buried in the soil in a final return.

This role of women is highly emphasized and interconnected with nature in a metaphorical depiction denoting the place of women in society. Woman's position in society is not confined to the domestic role of wife and mother. Rather, woman, like nature, is the fertile mother who gives hope and life. In "From Hiba's Diary", Tuqan idealized the role of woman as a resister in the image of a schoolgirl. She is a gift from the mother to the homeland. The "mother's phantom" with "her forehead" which "shines ...like the light of the stars". This interconnectedness between women and nature idealizes the image of women as a source of light guiding her daughter in this long path of residence. Even the "roses" she painted "reared with blood". This metaphorical image denotes the torture the schoolgirl has in Israeli prisons.

In her poem "Hamza", Toquan depicts the land as a fertile woman. The land of Palestine is shown as "a woman" who has "a fertile heart". It gives Palestinians the power to endure the suffering inflicted upon them 
by the Zionist colonizer. This land, undoubtedly, is "a woman" that "gives birth to a warrior".

Like mothers in my hometown

The salt of the earth

Who toil with their hands for their bread

Hamza was

A simple man.

When we met that day

This land had been a harvest of flames

In a windless bush it had sunk

In a cloak of barren grief. I had been

Swept by the daze of defeat.

Hamza said

This land, my sister, has a fertile heart

It throbs, doesn't wither, endures

For the secret of hills and wombs

Is one

This earth that sprout with spikes and palms

Is the same that gives birth to a warror,

This land, my sister, is a women,"

He said. (Tuqan)

This ecofeminist depiction stresses the interconnectedness between women and nature in a way that sets the scene and paves the way for her broad goal and the existence of a resistance that cannot be demolished. The idea of "a fertile woman" symbolizes birth and life. It refers to nature and women as a powerful form of resistance. Toquan succeeds in portraying the Palestinian woman as an active resister and not only as a wife and mother.

In "Lamps of dark night" Tuqan declares women's commitment to the on-going resistance against the "dark night" of colonization. She attempts to plant hope and light in the 
long road of regaining life.

Lamps of the dark night

Brothers in the wound...

On your road shall I walk

In the light of your eyes

I collect yesterday's tears

And wipe them away.

Like you, I plant my feet on the land,

My country,

And fix my eyes, like yours,

On the road of light and sun. (Tuqan 1990, 227)

Actually, images of resistance, resisters and colonizer can be traced from the first line of the poem. These images are connected with nature in a way that shows it in the body of resistance. Then, the interconnectedness between nature and women is depicted to show the role of women as a source of power and light to resisters. Definitely, it is the "road of light and sun". Undoubtedly, it is the ecofeminist treatment of images that gives theme their powerful impact to shed hope and energy to those who are connected to their homeland. Thus, elements of feminism and Nature are interconnected to depict the uniqueness of such powers of resistance.

\section{Ecofeminism in Linda Hogan' Poetry}

Linda Hogan, an environmentalist, and a Chickasaw novelist is a native of Denver Colorado earned her position among the environmentalists and feminists of today's society through her magnificent concentration on the Native American culture and the environment. An analysis of Hogan's history as an ecofeminism shows her steady contribution on an array of literature categories- spanning from short stories, academic works, playwrights, storytelling, and, more predominantly, poetry, that Pulitano (12) argues helps here audiences appreciate not only their smallness but also the giftedness and blessedness. Currently active as a speaker and educator, Hogan has played a central role in developing the poetry of Native America, particularly through exploring its association with the environment. Her strong presence as a poet has exalted her among female activists who, 
among other things, have the most influential voice regarding nuclear matters (Pulitano 67). Throughout her work, Hogan has always succeeded in incorporating the feminist aspect in her verses via the exploration of women's feelings and lives. Hogan is also an essayist who has taught at the University of Colorado.

Hogan's mark as an ecofeminist cannot be underrated because of her efforts to introduce readers to a generous visualization of nature (Pulitano 15). She manages to take her stories, novels, nonfictions, and poems as apparatus in her quest to enable people to appreciate the love of the created regime that coexists with the love of humanity. As per Hogan's view, being human entails accepting the earth as a planet and being responsive to the angles, secrets, and moods of nature. She advocates for the world where human being shows kindness to all form of life -including plants, animals, and minerals of the earth. Hogan enjoys the ability to stand in dread of earth's mysteries, which she presents as responsiveness to the grace that exists in nature. She carefully uses her polished, strange, and serene language to shock humanity awaken to the magnificence in their environment and emphasizes their part in it. Hogan's poetic collection includes " Calling Myself," " Eclipse," "Calling Myself Home," "Seeing Through the Sun," and "Terrain of Crossed Beginning" (Lee 11).

Hogan's poetic exploration of the theme of ecofeminism comes to the light as readers go through the carefully developed verses of "Mountain Lion," a piece that Hogan attests to have completed after taking part is projected that studied wolves in the northern banks of Minnesota. In her interview with Patricia Clark Smith, Hogan admits that the poem inspired by her observations during the project that opened her understanding of wolves as people's inner desire or fear, and how it was difficult to appreciate differences between the different species and between one human being and another. As per Hogan's understanding, people have the tendency to look for similarities - the shadow or the shadowed self- that enables one to view the external evil without acknowledging the inner evil (Pulitano 55). Hogan contends that these projections are no meagre psychological issues and that they have caused the extermination of thousands of wolves in the US (Lee 19). Hogan's "Mountain Lion,', is, therefore, founded on her pressing desire to support 


\section{Dr. Ahmad Mohammad Abd Al-salam Ahmad}

an environmental philosophy that conceives nature as neither separate from humanity nor a tabula rasa for inscriptions. The poetic piece evokes unmatched associations with nature while affirming nature's peculiarity by denying its limitations within human predictions.

"Mountain Lion" disdains a puzzled moment of unity even as it describes the persona's fearful experience with mountain lions. The author gives the mountain lions a unique perspective that overturns the customary categories of the wild and the civilized, a viewpoint in which the persona was "the wild" that she had learned to dread. The voice in the poem admits that the mountain lion does not like her presence when she quotes "her power lived ...in a dream of my leaving" (Kronlid 101). The acknowledgment of the speaker's unwelcomed presence gives the persona self-consciousness about the outcomes of her gaze as the glance she first gives the mountain lion and the subsequent turn-away function as a metonym for their aggravating relation (Mir 133). The "clear light" signifies enlightenment paradigm that came with the knowledge of the distance between the object and the subject, which consists of void space. The bareness then supposes to provide ideal access to clear knowledge as nothing hinders the penetration of the viewer's gaze. The persona refuses this model, however, by lowering her eyes and turning away. She rejects to entrap the mountain lion within the circumference of her gaze by looking away, an act that goes a long way showing her acknowledgment of the integrity of the mountain lion and the huge variations between the worlds that they live in (Kronlid 101).

Like the rests of Native American Writers, Linda Hogan imagines the landscape in its central interconnectedness with the people inhabiting it. Throughout her authorship, Hogan emphasizes the relationship between nonhuman and human nature, while maintaining focus on the disruption thereof, both of which have vivid impacts on people's sense of self. In her poem " Naming the Animals," Hogan analyzes the results of isolating humanity from nature, thus rejoining the Native American literature whose character focus on identity formation, which involves negotiating between the impact of the dominant society and their natural heritage (Shiva, Maria, \& Ariel 32). She, for example, finds a peculiar way to show how the language, and not the vision, has trapped the animal in "Naming the Animals" by retelling the biblical story of creation. 
Hogan deliberately leaves out Eve in the legend of creation, showing her ecofeminist assumption in bringing out Adam's act of naming animals as an action that both circumscribes and distances that which is given a name (Kronlid 13).

The naming, according to Hogan's narration, captured nature (the woman included) in language, apparently to screen them from human habitat, yet the subsequent act chases them "...into the wilderness" where he could not enter. Using human language to name the animals paradoxically registers them as separate from humanity. Hogan, like in all of her other works, advocates for an ecofeminist philosophy that highlights the connection between the domination of ethical, social, and sexual minorities, and the power of the non-human world. This grouping of women with nature, as illustrated in the ecofeminist theory, paves the way for understanding environmental and social environmental injustices from a peculiar and often ignorant perspective that encourages solace and solidarity (Kronlid 13). "Hunger" is a poem that shows Hogan's determination of writing about the injustices committed against women and nature. In this poem imagery is extensively used to reflect the poet's ecofeminist treatment of nature/women subordination. Hunger is personified as someone "who crosses oceans" and "sits on the ship and cries".

Hunger was the fisherman

who said dolphins are like women, we took them from the sea and had our way with them. (Hogan 17)

The image bears a sexual connotation that interconnects the exploitation of natural resources with that of women. Dolphins are "like women". They are used to satisfy the fishermen's needs. Even the sea is depicted in the figure of a pregnant woman:

It is the old man

who comes in the night

to cast a line

and wait at the luminous shore. 
He knows the sea is pregnant

with clear fish

and their shallow pools of eggs (17)

In their "Ties that Bind: Native American Consciousness as a Foundation for Environmental Consciousness.", Anne Booth and Harvey Jacobs states that "ecofeminism equates the suppression and domination of nature with the domination of women, and for similar reasons. Each was, and is perceived as dangerous and in need of control" (29). Hogan tries to heal the gap between the human and the non-human, emphasizing the need for a balanced connection that should pervades them. Hogan calls for a world that is kinder for both women and nature. She writes in "Harvesters of Night and Water":

I want the world to be kinder.

I am a woman.

I am afraid.

I saw a star once, falling toward me.

It was red

with brilliant arms

and then it was gone. (24)

\section{Critical Analysis of Hogan's and Tuqan's Approach to Ecofeminism Differences}

Hogan's and Tuqan's poetic works signify this difference between the contemporary American and classic Middle Eastern concepts of ecofeminism. Hogan, for example, presents a scenario where the human gaze objectifies the animal as the observed despite the fact that animals too can observe human beings (Lee 23). Hogan's acknowledgment of the differences between the natural and civil world supports the contemporary emphasis of the disjunction between marginalized groups and nature on one side and the developing world on the other. Even so, the notion that the persona, a woman, chooses to look away illuminates today's environmental issues as an outcome of lack of self-knowledge as a consequence of ignorance in as far as the comprehension of nature is concerned. Hogan's "Mountain Lion" lenses the existence of two parallel 
worlds despite the romantic desire for unity, which evokes a sense of conflict, as parallel worlds cannot coexist in one vision (Shoshan 56). These observations imply that Hogan, as one of the most famous contemporary American ecofeminist, focuses on the disjunction between the civil and the wild and the attrition of women (as part of humanity) from nature. The overarching argument is, therefore, that women beliefs systems permit the oppression of women as it permits the exploitive use of the earth.

Otherwise, Tuqan's piece "Labor Pain" underscores the early Arabic concept of ecofeminism in the sense that it prescribes the holistic comprehension of nature, and the feminine instincts as remedies to heal the split between nature and ecology. Unlike Hogan, Tuqan presents the world as a conflict scenario, where men and foreign power join forces against nature and women. The two poems justify this contention in various ways. For example, the idea that the early Middle-Eastern ecofeminist theory categorizes women in nature comes to light when Tuqan associates the pain that women undergo in childbirth with the experiences of torn wild fields that receive and support the seeds of rose flowers in "Labour Pain." The thorny rose plan is, otherwise classified with men who, despite evading the sacrificial duty, seek to dominate over women. The notion also pervades her work in "Mountainous Journey" where Tuqan describes her terrible childhood experience as a consequence of foreign power that has subjected Palestinian land to war and social norms that glorify men in families (Shoshan 56). As such, leading Tuqan's work is an ideology that sees women as a reflection of nature, where none is greater than the other.

\section{Similarities}

Even so, Hogan's and Tuqan's works provide insight into the similarities between American and Palestinian ecofeminist concepts. Hogan -whose female character chooses not to gaze at the mountain lion despite her natural desires- supports the viewpoint of Tuqan who embraces the essentialism to focus on the intersectional puzzles, such as how the culture-nature split supports the oppression of nonhuman and female bodies (Laroche \& Kronlid 78). For example, an analysis of the works of the two poets reveals that both Tuqan and Hogan believe in 
women as part of nature. Hogan, for instance, uses a female character as the voice in "Mountain Lion" to emphasize the similarities between the observed and the observer. She, like Tuqan in "Labor Pain," shows how fear and desire has pushed humanity to treat nature (including women) unfairly. These poems, including Tuqan's "Mountainous Journey," show the marginalization of groups and negative environmental outcomes as results of long-held principles that are founded on the male-centric society (Kronlid 101).

\section{Conclusion}

An analysis of Tuqan's and Hogan's poetic works shows strong ideas of ecofeminism, and this justifies the selection of their works in exploring the theory that explains nature in the context of human and men dominance (Shoshan 93). In essence, both Tuqan and Hogan gain their rightful appreciation as ecofeminists who have managed to use their poetic wits to advocate for an ecological philosophy where the connection between humanity and nature is viewed as one that demands to be fixed through respecting the differences and similarities between the two (Lee 133). The works of the two poets, as described in preliminary facets of the evaluation, show significant similarities between the early Palestinian concept of ecofeminism and that of contemporary American ecofeminist in that both deal with the themes of women and nature versus a malecentred society. Tuqan and Hogan go a long way using their feministic poetry to describe the destruction of nature as consequences of conceptual separation between nature and people. Both also believe that the problem could be solved through accepting a new ecological theory that accepts humanity and part of nature, and women as equivalents of men.

Environmental and cultural matters seem to influence the ecofeminist approaches that the two poets use. For instance, Tuqan, raised in a turbulent environment of war and tribulation, finds a junction between the suffering of women and the destruction of Palestinian motherland. The implication in this place is that American ecofeminist concept focuses majorly on understanding women as elements of nature while Palestinian concept seeks to battle the Arabic culture that diminishes women's societal position by emphasizing the connection between the fate of women and nature even as they suffer under the spell 
of war and oppression. Even so, the attrition between the contemporary and classic concepts of ecofeminism come to play as one compares the works of Tuqan- a classical feminist who visualizes women as equivalents of nature- and Hogan- a modern feminist who emphasizes natures as a force that is much greater than human beings. 


\section{Works Cited}

Booth, Annie L., and Harvey L. Jacobs. "Ties that Bind: Native American Consciousness as a Foundation for Environmental Consciousness." Environmental Ethics 12.1, 1990.27-43.

Gaard, Greta. "Women, Water, Energy: An Eco-feminist Approach," Organization and Environment, 14, No. 2, (2001). 157-172. Print.

Hadeed, Khalid W. Late Modern Arabic Literature: Gender As Crucible of Crisis. , 2012. Print.

Hogan, Linda. The Book of Medicines. Minneapolis: Coffee House, 1993.

Howel, Nancy. R. ."Ecofeminism: What One Needs to Know". Zygon 2, no.2, 1977.

Kronlid, David. Ecofeminism and Environmental Ethics: An Analysis of Ecofeminist Ethical Theory. Uppsala: Uppsala University Library [distributor, 2003. Print.

Laroche, Rebecca, and Jennifer Munroe. Shakespeare and Ecofeminist Theory. , 2017. Print.

Lee, A. R. Native American writing. London: Routledge, 2011.

Mir, Salam S. D. Guyanese and Palestinian Literatures: A Comparative Study of the Representation of the Theme of Resistance in the Development of Two World Literatures at Specific Historical Moments. , 2003. Print.

Pulitano, Elvira. Transatlantic Voices: Interpretations of Native North American Literatures. Lincoln: University of Nebraska Press, 2007. Print.

Rosiska, Darcy de Oliveira. Elogio da Diferença: O Feminino Emergente. San Paulo: Brasiliense, 1991.

Ruether, Rosemary Radford.. New Woman/New Earth: Sexist Ideologies and Human Liberation. New York: The Seabury Press, 1975. 
Sandilands, Kate. "Ecofeminist and Its Discontent: Notes Toward a Politic of Diversity." The Trumpeter 8 (2), 1991.

Shiva, Vandana, Maria Mies, and Ariel Salleh. Ecofeminism. London: Zed Books, 2014. Print.

Shoshan, Boaz. Discourse on Gender/gendered Discourse in the Middle East. Westport, Conn: Praeger, 2000. Print.

Sturge Legler, Gretchen T. 'Ecofeminist Literary Criticism.' Ecofeminism: Womm, Cultun, Nature. Ed. Karen J. Warren. Indianapolis: Indiana UP, 1997. 227-38. Print.

Sturgeon, Noel. (1997). Ecofeminist Natures. New York: Routledge, 1997. Print.

Tuqan, Fadwa. The HyperTexts.

http://www.thehypertexts.com/Fadwa\%20Tuqan\%20Palestinian\%20Poe t\%20Poetry\%20Picture\%20Bio.htm

Warren, Karen. "Feminism and Ecology: Making Connections." Environmental Ethics 9. 1987. 3-20. 